\title{
Unmet needs in emergency department patients as an important aspect of the increasing number of hospitalizations
}

\author{
KATARZYNA SZWAMEL ${ }^{1,2, A-G}$, DONATA KURPAS ${ }^{1,2, \text { D, E }}$ \\ ${ }^{1}$ Opole Medical School, Poland \\ ${ }^{2}$ Department of Family Medicine, Wroclaw Medical University, Poland
}

A - Study Design, B - Data Collection, C - Statistical Analysis, D - Data Interpretation, E - Manuscript Preparation, F - Literature Search, G - Funds Collection

Summary Background. Unmet needs in the medical care of high-need patients may increase costs due to the use of emergency departments (EDs) instead of primary care.

Objectives. To establish the possible correlation between the unmet needs of patients and the number of hospitalizations, and the probability of influence of the former aspect on the latter, and to analyze the level of satisfied needs of ED patients in relation to sociodemographic data.

Material and methods. An original questionnaire and a modified version of the Camberwell Assessment of Need Short Appraisal Schedule (CANSAS) were used to assess the level of satisfaction of the social, medical, psychological and environmental needs of 150 ED patients.

Results. Most respondents were women (54\%; 81/150) of a median age of 44.5 (range: $18-87$ ). Nearly a half of the patients (48\%; $72 / 150$ ) were treated due to chronic diseases. A high Camberwell index (above 0.825) was negatively correlated with the total number of hospitalizations in a three-year period $(r=-0.37 ; p<0.001)$. The chance of hospitalization in people with a low Camberwell index (below 0.825 ) was 3 times higher than in those with higher values (OR 0.36; $95 \% \mathrm{Cl} 0.17-0.72$ ). The highest level of satisfied needs was obtained by people aged 38-47, with higher education, married, living in a relationship, declaring a very good material status. Conclusions. An ED visit prevention program should include the target primary care patient groups with the highest chance of hospitalization, in particular: people aged over 67, with chronic diseases, with primary education only, widows/widowers, declaring a poor material status and living alone.

Key words: needs assessment, health services needs and demand, emergency service, hospital ward.

Szwamel K, Kurpas D. Unmet needs in emergency department patients as an important aspect of the increasing number of hospitalizations. Fam Med Prim Care Rev 2017; 19(3): 261-269, doi: https://doi.org/10.5114/fmpcr.2017.68753.

\section{Background}

The data from the report Health at a Glance (2015) shows that an average of approx. $3 \%$ of the population across Europe reported unmet needs for medical care due to costs, travel distance and waiting lists in 2013. Unmet needs were reported in larger shares of the population in Latvia (13.8\%), Greece (9\%), Poland $(8.8 \%)$ and Estonia (8.4\%), while less than $1 \%$ of the population reported unmet needs in the Netherlands $(0.4 \%)$, Austria (0.4\%) and Spain (0.8\%) [1]. In 2014, the value for Poland was slightly lower compared to $2013-7.8 \%$ of the total population (11\% for low income quintile and $4.8 \%$ for high income quintile) - with the average for $28 \mathrm{EU}$ states being 3.6\% [2].

Factors determining and modifying the level of patients' needs are: multimorbidity, physical limitations, sociodemographic characteristics (age, gender, level of income, level of education), relationship between the patient and the regular health care provider (quality of patient-provider communication, possibility of the patient's participation in diagnosis and therapy), access to the usual source of care, access to a specialist and after-hours care, comprehensiveness of care, responsiveness of care, receiving assistance in managing conditions (care coordinator) and insurance type (i.e. in the US, unmet needs were the greatest among high-need adults with private insurance $-32 \%$, followed by those with Medicaid alone - 28\%) [3-5].

The Commonwealth Fund survey focused on adults aged 65 and older with at least three chronic conditions or a functional limitation in the activities of daily living, and their health care experiences in high-income countries (Australia, Canada, France, Germany, the Netherlands, Norway, Sweden, Switzerland and the United States) showed that those patients are more likely to have seen four or more doctors in the past year, more likely to regularly take four or more prescription drugs and more likely to have visited the emergency department (ED) multiple times in the past two years. This group is called high-need patients. Poor performance in providing care for these patients may contribute to high costs due to the use of ED visits instead of primary care and overuse of care, particularly in relation to lab tests and imaging [6].

A study by Foo et al. [7], conducted in an ED in Singapore among patients aged 65 and older, confirmed a high level of unmet patients' needs; $82.9 \%$ of patients required some form of geriatric intervention, $65 \%$ were found to have significant fall risk, $61.4 \%$ had visual impairment, $58.2 \%$ had improper footwear, $44.3 \%$ had nocturia, $33.6 \%$ had problems with memory (cognition), $38.2 \%$ had mobility issues, $29.3 \%$ had sedentary lifestyle, $28.6 \%$ had social/career problems, $22.5 \%$ had incontinence, $19.6 \%$ had hearing problems, $17.5 \%$ had sleep disturbances, $15 \%$ had low mood/depression. The authors demonstrated that geriatric screening of at-risk elderly ED patients prior to discharge resulted in a consistent and sustained preservation of function lasting over 12 months.

The level of unmet needs of patients can also be associated with increased expectations from the health care system. Approximately one in five (19\%) high-need patients used ED for a condition that could have been treated in a doctor's office or 
a clinic [4]. This can be due to the need to find a convenient healthcare provider offering a high level of services. Patient-perceived poor and intermediate levels of primary care quality had more than twice higher odds of non-urgent ED care costs compared to high-quality care [8]. Multiple studies have shown patients reporting to EDs in cases not requiring immediate intervention [8-10]. For example, from 2006 to $2009,10.1 \%$ of US ED visits were categorized as non-urgent [11]. It is worth mentioning that with better access to care and good patient-provider communication, high-need patients are less likely to go to the emergency department to receive non-urgent care [4].

Increased ED visits are considered to be linked with loneliness, vulnerability and lack of family support. One study found that among older people without a family network, the likelihood of ED use increased sevenfold [12]. This phenomenon can correspond to an unmet need for belongingness and love, and according to Szatur-Jaworska [13], the immediate family is the principal source of social contact and satisfies the need to belong in a social group.

Barriers to accessing timely diagnostic and therapeutic procedures can determine the unmet needs of patients as well. According to the "Barometer" report by the Watch Health Care Foundation, the average waiting time for an endocrinology, angiology, urology, neurosurgery or cardiology specialist visit in Poland in 2016 was 4-9 months. The waiting time for an MRI examination exceeded 6 months, transthoracic Doppler echocardiography - 5 months, Doppler ultrasound of lower limbs and Holter ECG - 4 months [14]. Honigman et al. [11] claimed that many barriers to accessing timely outpatient care were associated with increased ED utilization.

While health care systems are increasingly focused on targeting high utilizers of care in an attempt to simultaneously improve outcomes and save money [4], researchers emphasize the importance of satisfying the health care needs of patients and indicate that these needs require a comprehensive evaluation. Such actions can prove helpful in the proper integration of the patient's health care resources and needs and, by determining the optimal range and direction of therapeutic and social interventions, can result in decreased costs of health care [15-17].

Accurate analysis of the level of satisfaction of the social, medical, psychological and environmental needs of ED patients is one of the necessary methods to introduce actions leading to improved quality of their lives and, consequently, decreased costs of health care. The assessment of the needs has three major advantages over other patient-reported outcomes: direct indication of resources needed, quantification of unmet needs and appropriate allocation of health resources, as well as identification of patients and subgroups with certain levels of needs and the consequent need-targeted prevention and early intervention [18].

\section{Objectives}

The aims of the study were: 1 ) determination of whether the level of unmet needs correlates significantly with the number of hospitalizations, 2) calculation of the probability of influence of unmet needs on the number of hospitalizations, as well as 3 ) analysis of the level of satisfaction of ED patients' needs in relation to sociodemographic data.

\section{Material and methods}

\section{Study population}

A cross-sectional study was conducted among 150 emergency department patients in Kedzierzyn-Kozle (Opole Voivodeship, Poland). The inclusion criteria were: at least 18 years of age, responding coherently without symptoms of disturbed perception, being an ED patient, providing consent to participation in the study. The exclusion criteria were: under 18 years of age, no logical contact, difficulties making participation impossible (e.g. vision disorders reported by the patient, foreign body in the eye, severe trauma, aggravated general condition), no consent for participation.

In the initial phase, 358 adult ED patients who potentially met the inclusion criteria were invited to participate in the study. In 4 patients, disturbances of logical contact were found during the study, although the symptoms did not appear in the initial phase. In 157 patients, difficulties occurred that prevented their further participation in the study (visual disorders $(n=$ $49)$, aggravated pain in any part of the body $(n=56)$, aggravated general condition of the patient $(n=52))$. Some of the patients ( $n=47)$ withdrew from the study due to lack of free time after discharge from hospital or lack of interest in further participation in the study. The final group consisted of 150 ED patients (Figure 1). eligible potential participants invited to participate in the study $n=358$

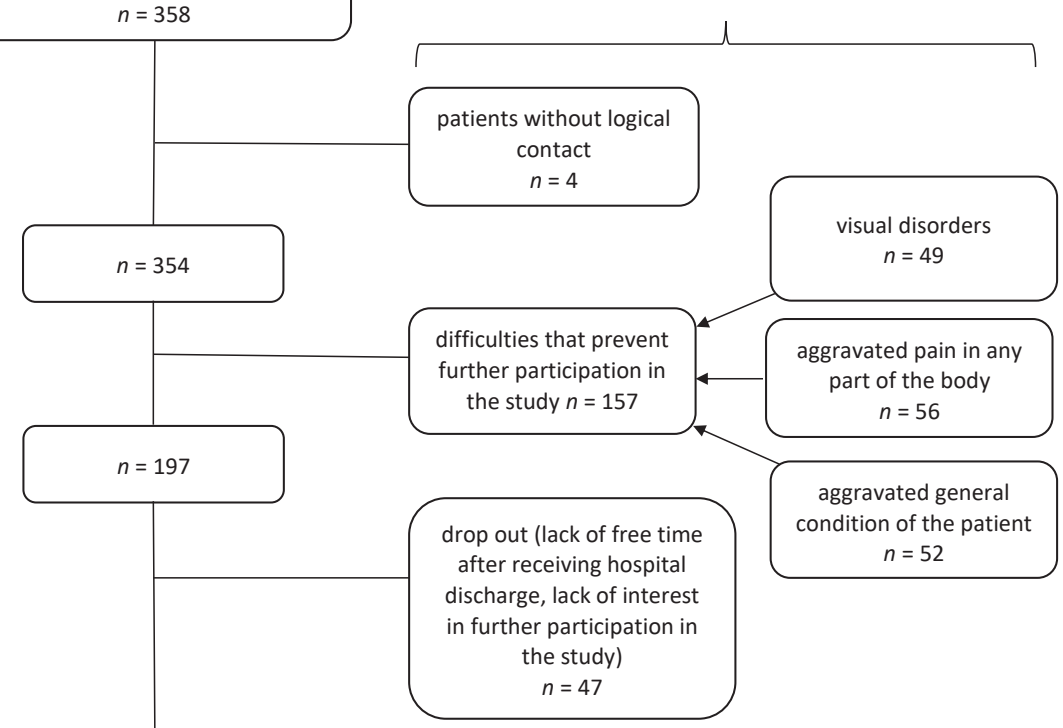

Figure 1. Flow diagram - reasons for non-participation at each stage of the study 
The majority of the respondents were women (54\%; 81). The median respondent age was 44.50 years (range: $18-87)$. The majority of those surveyed were married $(58.7 \% ; 88)$, de- clared average financial status (53.74\%; 79), had secondary education $(46.9 \% ; 69)$ and were residents of cities with a population of 20,000-100,000 (46.98\%; 70) (Table 1).

\begin{tabular}{|c|c|c|c|c|}
\hline \multicolumn{3}{|l|}{ Variables } & $n$ & $\%$ \\
\hline \multirow[t]{3}{*}{ Gender } & \multicolumn{2}{|l|}{ female } & 81 & 54,0 \\
\hline & \multicolumn{2}{|l|}{ male } & 69 & 46.0 \\
\hline & \multicolumn{2}{|l|}{ total } & 150 & 100.0 \\
\hline \multirow[t]{5}{*}{ Age (years) } & \multicolumn{2}{|l|}{$n$} & 150 & 100.0 \\
\hline & \multicolumn{2}{|l|}{ mean } & \multicolumn{2}{|c|}{47.03} \\
\hline & \multicolumn{2}{|l|}{ SD } & \multicolumn{2}{|c|}{18.57} \\
\hline & \multicolumn{2}{|l|}{$Q .25 \%-Q .50 \%-Q .75 \%$} & \multicolumn{2}{|c|}{$31.00-44.50-62.00$} \\
\hline & \multicolumn{2}{|l|}{$\min -\max$} & 18.0 & 87.0 \\
\hline \multirow[t]{5}{*}{ Education } & \multicolumn{2}{|l|}{ primary } & 11 & 7.5 \\
\hline & \multicolumn{2}{|l|}{ vocational } & 40 & 27.2 \\
\hline & \multicolumn{2}{|l|}{ secondary } & 69 & 46.9 \\
\hline & \multicolumn{2}{|l|}{ higher } & 27 & 18.4 \\
\hline & \multicolumn{2}{|l|}{ total } & 147 & 100.0 \\
\hline Marital status & unmarried & & 33 & 22.0 \\
\hline & married & & 88 & 58.7 \\
\hline & divorced & & 12 & 8.0 \\
\hline & widow/widower & & 17 & 11.3 \\
\hline & total & & 150 & 100.0 \\
\hline No. of household members & mean & & 3.04 & \\
\hline & SD & & 1.43 & \\
\hline & Q.25\%-Q.50\%-Q.75\% & & 2.00 & \\
\hline & $\min -\max$ & & 1.0 & 8.0 \\
\hline & total & & 150 & 100.0 \\
\hline Family material status & very poor & & 0 & 0.0 \\
\hline & poor & & 8 & 5.44 \\
\hline & average & & 79 & 53.74 \\
\hline & good & & 54 & 36.73 \\
\hline & very good & & 6 & 4.08 \\
\hline & total & & 147 & 100.0 \\
\hline Living in a regular relationship & yes & & 109 & 74.7 \\
\hline & no & & 37 & 25.3 \\
\hline & total & & 146 & 100.0 \\
\hline Place of residence & over 100,000 population (large & & 12 & 8.05 \\
\hline & $20,000-100,000$ population $(\mathrm{m}$ & sized city) & 70 & 46.98 \\
\hline & under 20,000 population (smal & wn) & 18 & 12.08 \\
\hline & village & & 49 & 32.89 \\
\hline & total & & 149 & 100.0 \\
\hline Coexisting chronic diseases & no & & 78 & 52.0 \\
\hline & yes & & 72 & 48.0 \\
\hline & cardiovascular diseases & no & 96 & 64.0 \\
\hline & & yes* & 54 & 36.0 \\
\hline & respiratory diseases & no & 135 & 90.0 \\
\hline & & yes* & 15 & 10.0 \\
\hline & musculoskeletal diseases & no & 131 & 87.3 \\
\hline & & yes* & 19 & 12.7 \\
\hline & urinary tract diseases & no & 133 & 88.7 \\
\hline & & yes* & 17 & 11.3 \\
\hline & endocrine system diseases & no & 118 & 78.7 \\
\hline & & yes* & 32 & 21.3 \\
\hline & nervous system diseases & no & 142 & 94.7 \\
\hline & & yes* & 8 & 5.3 \\
\hline & gastrointestinal tract diseases & no & 129 & 86.0 \\
\hline & & yes* & 21 & 14.0 \\
\hline
\end{tabular}




\section{Data collection}

The study was conducted among anonymous and voluntary participants between November 2014 and September 2015. Prior to participation, the patients were informed about the aims of the study and the expected benefits. The participants were made aware that withdrawal without consequences was possible at any point of the study. Returning the completed questionnaire was considered as the patient's consent for participation in the study. All procedures followed the Declaration of Helsinki (revised in 2000), and the study was approved by the Bioethical Commission of Wroclaw Medical University (approval no. KB-673/2014).

\section{Questionnaires}

The study was conducted using a diagnostic survey with two different questionnaires. One of these was an original questionnaire containing questions about sociodemographics, number of hospitalizations in the 3 years preceding the study (2012-2014), number of medicines currently taken, number and duration of chronic diseases. The second questionnaire was a modified version of the Camberwell Assessment of Need Short Appraisal Schedule (CANSAS).

A modified version of CANSAS was designed to discuss 22 different subject matters concerning problems experienced by patients suffering from chronic somatic diseases and not suffering from severe mental disorders [19]. CANSAS contains questions regarding: housing conditions, personal care abilities, everyday activity, physical and mental health, psychological stress, addictions (medicines, illegal drugs, alcohol), social contacts, intimate relationships, ability to use a phone, ability to use public transport, making personal economic decisions [20]. It allows for assessment of the level of satisfaction of an individual's social, medical, psychological and environmental needs [21].

Calculation of the Camberwell index was conducted using the following procedure: based on 24 questions regarding 22 needs, the total number $(n)$ of needs marked as satisfied (1) or unsatisfied $(0)$ was determined. If no satisfaction level of a need could be determined due to a lack of answers, the need was omitted. Subsequently, the number of satisfied needs (M) was calculated based on the total number $(n)$ of needs indicated by the participant. The Camberwell index was then calculated as the $\mathrm{M} / \mathrm{N}$ ratio. The internal consistency of the modified version of CANSAS measured with the $\alpha$-Cronbach coefficient was 0.82 [19].

\section{Statistical analysis}

In order to analyze and interpret the questions in CANSAS, the number $(n)$ and percentage of obtained answers were calculated for every question. The normality of distribution of quantitative variables was verified using the Shapiro-Wilk test with a statistical significance at $p<0.05$. The variables of "number of chronic diseases" and "number of hospitalizations" were characterized by a distribution corresponding to normal; therefore, their mean values and standard deviations were always used for their interpretation. For the remaining variables, whose distribution did not correspond to normal, median, minimum and maximum values were given. The strength and direction of correlation between the Camberwell index and number of hospitalizations in a three-year period were calculated using the Spearman's rank-order correlation coefficient, while the probability of correlation of these two variables was determined using logistic regression. A 95\% confidence interval was used for the odds ratio.

For testing hypotheses for means in the case of the Camberwell variable, the Kruskal-Wallis rank test was used. In this case, rejecting the null hypothesis meant that at least one mean was significantly different from the other means. R 3.0.2 (for Mac OS X) statistical software and Excel 2013 were used for analysis of the data.

\section{Results}

In the investigated group, $48 \%(72 / 150)$ of patients were treated due to chronic diseases. The mean number of chronic diseases was $1.58 \pm 2.23$, while their median duration was 6.35 years (min-max: $1.00-21.75$ years). The median number of medicines taken by an ED patient was 4.5 tablets per day (min-max: 0-16). The mean number of ED hospitalizations per patient during a three-year follow-up was $2.63 \pm 2.84$, while that of total hospitalizations (in ED and other departments) was 1.39 \pm 2.13 .

The median Camberwell index of satisfaction of needs was 0.825 (min-max: $0.21-1.00$ ). It was presumed that a value of the Camberwell index above median indicates a high level of satisfied needs, while that below median indicates a low level of satisfied needs. A high Camberwell index (over 0.825) correlated negatively with the total number of hospitalizations in the three-year period $(r=-0.37 ; p<0.001)$. Moreover, the chance of hospitalization in people with a low index of satisfied needs (Camberwell index under 0.825) was 3 times greater than in people with an index over 0.825 (OR 0.36 ; 95\% $\mathrm{Cl} 0.17-0.72$ ).

The highest degree ( $>70 \%$ ) of satisfied needs of ED patients was obtained in the following areas: housing conditions, preparation of meals and household maintenance abilities, personal care, obtaining information about medicines and treatment, lack of problems related to the consumption of alcohol and illegal drugs, social contacts, intimate relations (in people having a partner), relations with children (in people having them), ability to use a phone, making personal economic decisions, receiving public benefits.

The level of satisfied needs regarding: everyday activity, physical and mental health, sexual life, no will to have a partner, was $60-69.99 \%$. Between $50 \%$ and $59.99 \%$ of the respondents indicated a lack of psychological stress. Only $31.08 \%$ of patients took solely medicines prescribed by their physician (which means that the remaining patients took other medicines without recommendation by a physician). Only a small group of $20 \%$ of patients without children still expressed the will to have them (Table 2).

\begin{tabular}{|c|c|c|c|c|c|}
\hline \multirow[t]{2}{*}{ No. } & \multirow[t]{2}{*}{ Needs } & $n$ & \multirow[t]{2}{*}{ met } & \multirow[t]{2}{*}{ unmet } & \multirow[t]{2}{*}{ total } \\
\hline & & $\%$ & & & \\
\hline \multirow[t]{2}{*}{1.} & \multirow[t]{2}{*}{ Accommodation } & $n$ & 145 & 5 & 150 \\
\hline & & $\%$ & 96.67 & 3.33 & 100 \\
\hline \multirow[t]{2}{*}{2.} & \multirow{2}{*}{$\begin{array}{l}\text { Food and grocery } \\
\text { (shopping) }\end{array}$} & $n$ & 127 & 23 & 150 \\
\hline & & $\%$ & 54.67 & 15.33 & 100 \\
\hline \multirow[t]{2}{*}{3.} & \multirow[t]{2}{*}{ Looking after home } & $n$ & 131 & 19 & 150 \\
\hline & & $\%$ & 87.33 & 12,67 & 100 \\
\hline \multirow[t]{2}{*}{4.} & \multirow[t]{2}{*}{ Self-care home } & $n$ & 114 & 25 & 139 \\
\hline & & $\%$ & 82.01 & 17.99 & 100 \\
\hline \multirow[t]{2}{*}{5.} & \multirow[t]{2}{*}{ Daytime activities } & $n$ & 102 & 46 & 148 \\
\hline & & $\%$ & 68.92 & 31.08 & 100 \\
\hline \multirow[t]{2}{*}{6.} & \multirow[t]{2}{*}{ Physical health } & $n$ & 98 & 49 & 147 \\
\hline & & $\%$ & 66.67 & 33.33 & 100 \\
\hline \multirow[t]{2}{*}{7.} & \multirow[t]{2}{*}{ Psychical health } & $n$ & 74 & 33 & 107 \\
\hline & & $\%$ & 69.16 & 30.84 & 100 \\
\hline \multirow[t]{2}{*}{8.} & \multirow{2}{*}{$\begin{array}{l}\text { Information on } \\
\text { condition and } \\
\text { treatment }\end{array}$} & $n$ & 118 & 12 & 130 \\
\hline & & $\%$ & 90.77 & 9.23 & 100 \\
\hline \multirow[t]{2}{*}{9.} & \multirow{2}{*}{$\begin{array}{l}\text { Psychological } \\
\text { distress }\end{array}$} & $n$ & 80 & 65 & 145 \\
\hline & & $\%$ & 55.17 & 44.83 & 100 \\
\hline
\end{tabular}




\begin{tabular}{|c|c|c|c|c|c|}
\hline \multirow[t]{2}{*}{ No. } & \multirow[t]{2}{*}{ Needs } & $n$ & \multirow[t]{2}{*}{ met } & \multirow[t]{2}{*}{ unmet } & \multirow[t]{2}{*}{ tota } \\
\hline & & $\%$ & & & \\
\hline \multirow[t]{2}{*}{10.} & \multirow{2}{*}{$\begin{array}{l}\text { Drinking alcohol } \\
\text { and problems } \\
\text { associated with } \\
\text { drinking }\end{array}$} & $n$ & 78 & 9 & 87 \\
\hline & & $\%$ & 89.66 & 10.34 & 100 \\
\hline \multirow[t]{2}{*}{11.} & \multirow[t]{2}{*}{ Narcotics } & $n$ & 137 & 7 & 144 \\
\hline & & $\%$ & 95.14 & 4.86 & 100 \\
\hline \multirow[t]{2}{*}{12.} & \multirow{2}{*}{$\begin{array}{l}\text { Medicines that are } \\
\text { not prescribed }\end{array}$} & $n$ & 46 & 102 & 148 \\
\hline & & $\%$ & 31.08 & 68.92 & 100 \\
\hline \multirow[t]{2}{*}{13.} & \multirow[t]{2}{*}{ Social life } & $n$ & 119 & 24 & 143 \\
\hline & & $\%$ & 83.22 & 16.78 & 100 \\
\hline \multirow[t]{2}{*}{14.} & \multirow{2}{*}{$\begin{array}{l}\text { Intimate relation- } \\
\text { ships }\end{array}$} & $n$ & 17 & 10 & 27 \\
\hline & & $\%$ & 62.96 & 37.04 & 100 \\
\hline \multirow[t]{2}{*}{15.} & \multirow{2}{*}{$\begin{array}{l}\text { Satisfaction with } \\
\text { intimate relation- } \\
\text { ships }\end{array}$} & $n$ & 71 & 19 & 90 \\
\hline & & $\%$ & 78.89 & 21.11 & 100 \\
\hline \multirow[t]{2}{*}{16.} & \multirow{2}{*}{$\begin{array}{l}\text { Satisfaction with } \\
\text { sexual life }\end{array}$} & $n$ & 94 & 42 & 136 \\
\hline & & $\%$ & 69.12 & 30.88 & 100 \\
\hline \multirow[t]{2}{*}{17.} & \multirow{2}{*}{$\begin{array}{l}\text { Need of having } \\
\text { children }\end{array}$} & $n$ & 6 & 24 & 30 \\
\hline & & $\%$ & 20 & 80 & 100 \\
\hline \multirow[t]{2}{*}{18.} & \multirow{2}{*}{$\begin{array}{l}\text { Satisfaction with } \\
\text { relationship with } \\
\text { children }\end{array}$} & $n$ & 83 & 7 & 90 \\
\hline & & $\%$ & 92.22 & 7.78 & 100 \\
\hline \multirow[t]{2}{*}{19.} & \multirow{2}{*}{$\begin{array}{l}\text { Possibility of } \\
\text { communication by } \\
\text { phone }\end{array}$} & $n$ & 141 & 5 & 146 \\
\hline & & $\%$ & 96.58 & 3.42 & 100 \\
\hline \multirow[t]{2}{*}{20.} & \multirow{2}{*}{$\begin{array}{l}\text { Possibility of using } \\
\text { public transport }\end{array}$} & $n$ & 76 & 27 & 103 \\
\hline & & $\%$ & 73.79 & 26.21 & 100 \\
\hline
\end{tabular}

Table 2. Camberwell Assessment of Need Short Appraisal Schedule - interpretation

\begin{tabular}{|l|l|l|l|l|l|}
\hline \multirow{2}{*}{ No. } & Needs & $n$ & met & unmet & total \\
\cline { 3 - 4 } & & $\%$ & & & \\
\hline \multirow{2}{*}{21.} & \multirow{2}{*}{$\begin{array}{l}\text { Ability to budget } \\
\text { own money }\end{array}$} & $n$ & 126 & 18 & 144 \\
\cline { 3 - 6 } & $\%$ & 87.5 & 12.5 & 100 \\
\hline 22. & $\begin{array}{l}\text { Receiving all funds } \\
\text { entitled to }\end{array}$ & $n$ & 51 & 18 & 69 \\
\cline { 3 - 6 } & $\%$ & 73.91 & 26.09 & 100 \\
\hline
\end{tabular}

Additionally, analysis of the level of satisfied needs in relation to sociodemographic variables was conducted. The Camberwell index of satisfied needs depended, in a statistically significant manner, on: age, existence of chronic diseases, level of education, marital status, material status and living in a relationship.

The highest index values were obtained by people aged 38-47 years, and the lowest index values were obtained by people over 67 years of age, with means of 0.89 and $0.58(p<0.001)$, respectively. Higher values were reported for people without chronic diseases, and lower values were reported for those suffering from chronic diseases, with means of 0.83 and 0.70 $(p<0.001)$, respectively. The highest values were obtained by people with higher education, while the lowest values were obtained by those with primary education, with means of 0.83 and $0.57(p=0.001)$, respectively. The highest values were obtained by married people, while the lowest values were obtained by widows/widowers, with means of 0.81 and $0.59(p<0.001)$, respectively. Moreover, the highest values were obtained by people with a very good material status, while the lowest values were obtained by those with poor material status, with means of 0.91 and $0.54(p=0.001)$, respectively. Higher values were obtained by people living in a relationship, while lower values were obtained by those living alone, with means of 0.81 and $0.65(p<0.001)$, respectively.

The Camberwell index did not depend significantly on the number of family members, gender or place of residence (Table 3 ).

\begin{tabular}{|c|c|c|c|c|c|c|c|c|c|c|c|}
\hline & $n$ & M & SD & Me & Q25 & Q75 & $\min$ & $\max$ & kW & dif & $p$ \\
\hline \multicolumn{12}{|l|}{ Age } \\
\hline $18-27$ & 28 & 0.77 & 0.12 & 0.82 & 0.70 & 0.84 & 0.58 & 1.00 & \multirow[t]{6}{*}{37.47} & \multirow[t]{6}{*}{5} & \multirow[t]{6}{*}{0.001} \\
\hline $28-37$ & 28 & 0.82 & 0.18 & 0.89 & 0.77 & 0.94 & 0.26 & 1.00 & & & \\
\hline $38-47$ & 23 & 0.89 & 0.07 & 0.89 & 0.88 & 0.94 & 0.65 & 1.00 & & & \\
\hline $48-57$ & 22 & 0.80 & 0.13 & 0.84 & 0.73 & 0.89 & 0.50 & 0.95 & & & \\
\hline $58-67$ & 26 & 0.74 & 0.16 & 0.77 & 0.63 & 0.84 & 0.33 & 1.00 & & & \\
\hline$>67$ & 23 & 0.58 & 0.22 & 0.53 & 0.41 & 0.74 & 0.21 & 0.95 & & & \\
\hline \multicolumn{12}{|c|}{ Treatment for chronic diseases } \\
\hline No & 78 & 0.83 & 0.13 & 0.87 & 0.77 & 0.94 & 0.50 & 1 & \multirow[t]{2}{*}{17.89} & \multirow[t]{2}{*}{1} & \multirow[t]{2}{*}{0.001} \\
\hline Yes & 72 & 0.70 & 0.20 & 0.74 & 0.58 & 0.88 & 0.21 & 1 & & & \\
\hline \multicolumn{12}{|l|}{ Gender } \\
\hline Female & 81 & 0.77 & 0.17 & 0.83 & 0.67 & 0.89 & 0.26 & 1 & \multirow[t]{2}{*}{0.01} & \multirow[t]{2}{*}{1} & \multirow[t]{2}{*}{0.903} \\
\hline Male & 69 & 0.77 & 0.19 & 0.82 & 0.67 & 0.89 & 0.21 & 1 & & & \\
\hline \multicolumn{12}{|l|}{ Education } \\
\hline \begin{tabular}{|l} 
Primary \\
\end{tabular} & 11 & 0.57 & 0.21 & 0.50 & 0.46 & 0.70 & 0.26 & 0.95 & \multirow[t]{4}{*}{14.80} & \multirow[t]{4}{*}{3} & \multirow[t]{4}{*}{0.001} \\
\hline Vocational & 40 & 0.73 & 0.19 & 0.76 & 0.62 & 0.88 & 0.35 & 1.00 & & & \\
\hline Secondary & 69 & 0.80 & 0.16 & 0.83 & 0.72 & 0.90 & 0.21 & 1.00 & & & \\
\hline Higher & 27 & 0.83 & 0.13 & 0.88 & 0.78 & 0.92 & 0.50 & 1.00 & & & \\
\hline \multicolumn{12}{|c|}{ Marital status } \\
\hline Single & 33 & 0.76 & 0.15 & 0.79 & 0.70 & 0.85 & 0.26 & 1.00 & \multirow[t]{4}{*}{22.70} & \multirow[t]{4}{*}{3} & \multirow[t]{4}{*}{0.001} \\
\hline Married & 88 & 0.81 & 0.15 & 0.88 & 0.75 & 0.94 & 0.33 & 1.00 & & & \\
\hline Divorced & 12 & 0.71 & 0.27 & 0.85 & 0.50 & 0.94 & 0.21 & 0.95 & & & \\
\hline Widowed & 17 & 0.59 & 0.16 & 0.61 & 0.47 & 0.72 & 0.35 & 0.84 & & & \\
\hline
\end{tabular}




\begin{tabular}{|c|c|c|c|c|c|c|c|c|c|c|c|}
\hline & $n$ & M & SD & Me & Q25 & Q75 & $\min$ & $\max$ & kW & $d f$ & $p$ \\
\hline \multicolumn{12}{|c|}{ Number of persons in the household } \\
\hline $1-4$ & 128 & 0.77 & 0.18 & 0.82 & 0.67 & 0.90 & 0.21 & 1 & \multirow[t]{2}{*}{0.16} & \multirow[t]{2}{*}{1} & \multirow[t]{2}{*}{0.688} \\
\hline $5-8$ & 22 & 0.78 & 0.19 & 0.88 & 0.66 & 0.89 & 0.33 & 1 & & & \\
\hline \multicolumn{12}{|c|}{ Material status } \\
\hline Poor & 8 & 0.54 & 0.28 & 0.46 & 0.33 & 0.84 & 0.21 & 0.89 & \multirow[t]{4}{*}{15.42} & \multirow[t]{4}{*}{3} & \multirow[t]{4}{*}{0.001} \\
\hline Average & 79 & 0.75 & 0.18 & 0.79 & 0.65 & 0.89 & 0.26 & 1.00 & & & \\
\hline Good & 54 & 0.82 & 0.13 & 0.86 & 0.73 & 0.94 & 0.50 & 1.00 & & & \\
\hline Very good & 6 & 0.91 & 0.07 & 0.91 & 0.85 & 0.94 & 0.82 & 1.00 & & & \\
\hline \multicolumn{12}{|c|}{ Living in a relationship } \\
\hline No & 37 & 0.65 & 0.20 & 0.69 & 0.50 & 0.80 & 0.21 & 1 & \multirow[t]{2}{*}{18.15} & \multirow[t]{2}{*}{1} & \multirow[t]{2}{*}{0.001} \\
\hline Yes & 109 & 0.81 & 0.15 & 0.85 & 0.72 & 0.94 & 0.33 & 1 & & & \\
\hline \multicolumn{12}{|c|}{ Place of residence } \\
\hline Urban & 100 & 0.77 & 0.18 & 0.83 & 0.69 & 0.89 & 0.26 & 1 & \multirow[t]{2}{*}{0.003} & \multirow[t]{2}{*}{1} & \multirow[t]{2}{*}{0.959} \\
\hline Rural & 49 & 0.77 & 0.18 & 0.83 & 0.64 & 0.90 & 0.21 & 1 & & & \\
\hline
\end{tabular}

$n$ - number of observations, M - mean, SD - standard deviation, Me - median, Q25 - first quartile, Q75 - third quartile, KW - Kruskal-Wallis test, $d f$ - number of degrees of freedom, $p$ - level of significance.

\section{Discussion}

To improve public health, health care systems are required to be designed to meet people's needs [22]. Needs have to be satisfied for "maintaining homeostasis" [23].

In our study, we demonstrated that ED patients with a low level of satisfied needs, as measured by the Camberwell index, had a 3 times greater chance of hospitalization compared to those with a high level of satisfied needs. Ryan et al. [4] claimed that, compared to the general population, the high-need population was older, had lower levels of education and income and included more women. The majority of our results correspond to the above claim, as it was demonstrated that age correlated, in a statistically significant manner, with the level of needs of the surveyed patients; the lowest Camberwell index values were reported for people over 67 years of age. This can be partly due to the fact that the risk of developing de novo multimorbidity increases steeply with older age [24] and the fact that both physical and mental capabilities become limited with age [7].

\section{Multimorbidity and level of needs in patients}

In our study, almost half of the surveyed ED patients declared coexisting chronic diseases. Currently, an estimated 50 million people in Europe live with multiple chronic conditions (multimorbidity), and this number will further increase in the next decade [25]. Our outcomes confirm that the Camberwell index was lower, in a statistically significant manner, in the group with chronic diseases compared to that without chronic diseases. The low level of satisfied needs among people with chronic diseases is confirmed by the results obtained by Kurpas et al. [26]. The authors suggested that a low Camberwell index was more frequently reported by seniors $(r=-0.28 ; p=0.001)$, not in a relationship $(r=0.24 ; p=0.001)$, with a low level of QoL in a social relationship domain $(r=0.62 ; p<0.001)$ and those with a high number of chronic diseases $(r=-0.40 ; p<0.001)$. People with a low number of chronic diseases (1) have an approx. 50 times greater chance of having a high Camberwell index compared to those with a high number of chronic diseases (15) [26].

Multimorbidity is usually associated with the phenomenon of polypragmasia. Adverse effects of drugs lead to $11 \%$ of ED visits in patients older than 65 years versus $1-4 \%$ in the general population [27]. In our study, the median number of medicines taken by an ED patient per day was 4.5 tablets. Due to the above, the result showing that only $31.08 \%(46 / 148)$ of patients took only medicines prescribed by a doctor is particularly interesting. This means that a group of $68.92 \%(102 / 148)$ took additional medicines without a physician's prescription, which in turn is associated with an increased risk of adverse drug interactions and suggests an unmet need for being adequately treated.

\section{Impact of social relationships and level of needs}

In this study, we also confirmed that people living alone, widows and widowers have a higher level of unmet needs compared to people living in a relationship. Lack of satisfaction in the area of intimate relationships among people not having a partner was indicated in $37.04 \%(10 / 27)$ of cases. As many as $80 \%(24 / 30)$ of surveyed patients not having children declared the will to have them. A correlation between the high level of needs and social isolation is indicated by Ryan et al. [4]. In this study, a group of $37 \%$ high-need patients reported often feeling socially isolated (compared to $15 \%$ of other adults), $62 \%$ reported stress or worry about material hardships (compared to only one-third (32\%) of other adults), and $59 \%$ were somewhat or highly concerned about being a burden to family or friends [4]. According to the surveys of the Central Statistical Office of Poland (GUS), the total level of social isolation in Poland is $8.9 \%$ and is higher in men (9.8\%) than in women (8.1\%) [28]. According to the National Council on Aging, an estimated $17 \%$ of all Americans over the age of 65 are socially isolated [29]. As social isolation might be linked to hospital admissions among older people with chronic conditions, practitioners need to consider wider determinants of hospital admission, including social structures and support [30].

\section{Physical health and level of needs}

In a study by Salvi et al. [31], 74\% of older patients reported a functional decline resulting from the initial symptoms determined during their ED consultation. Laudisio et al. [32] suggested that in 342 subjects aged 75+ living in Tuscany (Italy), disability in relation to ADLs (Activities of Daily Living) was associated with an increased risk of ER visits (OR 2.12; 95\% Cl 1.11-4.08; $p=0.023)$. In the present study, a group of $33.33 \%(49 / 147)$ of ED patients had unmet needs regarding physical health, $12.67 \%$ $(19 / 150)$ could not conduct household maintenance, $17.99 \%$ $(25 / 139)$ had difficulties with personal care at home, and $31.08 \%(46 / 148)$ had unmet needs in daytime activity.

It can be observed that these percentage values are low, as the presented variables included in the Camberwell index were 
analyzed for the entire investigated group whose median age was relatively young: 44.5 years. An analysis per each age subgroup would probably indicate that these values are much higher in the elderly. This hypothesis is supported by, for example, studies in the US population. In 2014, the prevalence of disability in the US was: $10.8 \%$ in people aged 21 to $64,25.6 \%$ in people aged 65 to 74 and $50.3 \%$ in people aged 75 and older [33].

\section{Mental health and level of needs}

Emergency department use is higher in high-need adults with a behavioral health condition (depression, anxiety, alcohol- or substance-related disorder, serious mental illness) compared to the total adult population (683 per 1,000 population vs. 183 per 1,000 population, respectively) [34]. Feeling depressed is associated with higher rates of ED attendance and ambulance use $[35,36]$. In the present study, unmet needs in the area of mental health were reported by $30.84 \%$ (33/107) of ED patients, psychological distress was reported by $44.83 \%$ (65/145), while problems associated with drinking alcohol were reported by $10.34 \%(9 / 87)$. Depression can be present in up to one-third of older ED patients [27].

Nowicka-Sauer et al. [37] confirmed that anxiety and depression were the most frequent emotional reactions among patients with chronic diseases with a mean age of $53.41 \pm$ 13.1; increased anxiety level was observed in $42.7 \%$, while an increased depression level was observed in $26.7 \%$ of patients [37]. Moreover, depression and anxiety that accompany chronic diseases can lead to an increased number of diagnostic tests and consultations, which may lead to as much as doubling treatment costs [38].

\section{Level of needs and material status}

In our study, we also demonstrated that the highest value of the Camberwell index, in a statistically significant manner, was obtained by people with very good material status, while the lowest value was obtained by those with poor material status. Material status is positively correlated with the level of satisfied needs. In the study by Lofters et al. [39], Mobility Clinic patients with disabilities, compared to the general patient population, were twice as likely to report an annual household income of less than $\$ 40,000$ (58.6\% vs. $29.2 \% ; p=0.006)$ and had visited the emergency department at least once in the preceding year (compared to $29.7 \%$ in the general patient population $(p=0.027))$.

High-need patients often face financial problems and often skip recommended tests, treatment or follow-up because of costs or not filling prescriptions [6]. Overall, the most common reason for not having a medical examination or treatment in the EU-28 was that it was too expensive; this reason alone accounted for one-third of all people who reported an unmet need regarding medical care, equivalent to $2.4 \%$ of the population [5]. In 2014 in the EU states, poor people declared unmet medical needs for financial reasons an average of three times more frequently that rich people. People who forgo health care when they need it may jeopardize their health status [2]. In community-dwelling disabled elderly people, lack of medication assistance to those needing medication support was associated with a higher risk of hospitalization [40]. It is worth noting that the cessation of medication for economic reasons by patients with chronic diseases is usually costly to the health care system, be- cause medical costs associated with the consequences of such proceedings considerably exceed the cost of medication [19].

\section{Level of needs and education}

The Camberwell index of satisfied needs in our study was significantly dependent on the level of education; the highest value was obtained by people with higher education, while the lowest values were obtained by those with primary education. This general pattern of increasing unmet needs with decreasing educational attainment was observed in Latvia, Greece, Romania, Poland and Italy. In the EU-28 in 2014, 1.9\% of people having completed tertiary education reported unmet needs for a medical examination or treatment due to being too expensive, too far to travel or due to waiting lists; this share reached $3.3 \%$ for people having completed upper secondary or postsecondary non-tertiary education and $5.2 \%$ for people having completed, at most, lower secondary education [5].

\section{Level of needs and gender}

In our study, no significant correlation between the gender of the patients and the level of their needs as measured by the Camberwell index was found, but Hayes et al. [34], who conducted a study in the US, indicated that more women were classified as high-need patients. Moreover, in a study by Kurpas et al. [26], there was no statistically significant correlation between the values of the Camberwell index and gender. However, the results obtained by Hayes et al. [34] could be rationally explained by the feminization and singularization of old age, as well as poverty among elderly women [41-43].

Considering patients' needs is very important, as every increase in the level of unsatisfied medical needs can result in a decrease in the health status of the population, thereby contributing to increased inequality in health-related matters [2].

\section{Limitations of the study}

Some ED patients, especially elderly, in an aggravated general condition or disabled in relation to senses, could not fill out the questionnaire, which excluded them from the study and prevented us from measuring the level of satisfaction of needs in this group. Moreover, a comparative analysis of patients who were characterized by similar sociodemographic data and a profile of unmet needs using medical services in EDs and primary care units was omitted.

\section{Conclusions}

A low level of satisfied needs significantly increases the chance of hospitalization in ED patients. An ED visit prevention program, aiming at increasing the level of satisfied needs, should include the target primary care patient groups with the highest chance of hospitalization, in particular: people aged over 67, with chronic diseases, with primary education only, widows/ /widowers, declaring poor material status and living alone (as opposed to those living in a relationship). Future studies should be focused on the association between the number and causality of patient visits in EDs, the level of unsatisfied needs and the barriers preventing access to outpatient care (both primary and specialist), including the amount of out-of-pocket payments. 


\section{References}

1. Health at a Glance 2015: OECD Indicators. OECD Publishing, Paris [serial online] 2015 Nov [cited 11.02.2017]. Available from URL: http://dx.doi.org/10.1787/health_glance-2015-en.

2. Health at a Glance: Europe 2016: State of Health in the EU Cycle. OECD Publishing [serial online] 2016 Nov [cited 11.02.2017]. Available from URL: http://www.oecd.org/health/health-at-a-glance-europe-23056088.htm.

3. Salzberg CA, Hayes SL, McCarthy D, et al. Health system performance for the high-need patient: a look at access to care and patient care experiences. Issue Brief (Commonw Fund) 2016; 27(8): 1-12.

4. Ryan J, Abrams MK, Doty MM, et al. How high-need patients experience health care in the United States. Findings from the 2016 commonwealth fund survey of high-need patients. Issue Brief (Commonw Fund) 2016; 43(10): 1-20.

5. Eurostat. Unmet health care needs statistics 2016 [serial online] 2016 May [cited 11.02.2017]. Available from URL: http://ec.europa. eu/eurostat/statistics-explained/index.php/Unmet_health_care_needs_statistics.

6. Sarnak DO, Ryan J. How high-need patients experiences the health care system in nine countries. Issue Brief (Commonw Fund) 2016; 1(1): $1-14$.

7. Foo $\mathrm{CL}$, Siu VW, Ang $\mathrm{H}$, et al. Risk stratification and rapid geriatric screening in an emergency department - a quasi-randomised controlled trial. BMC Geriatr 2014; 14(1): 98, doi: 10.1186/1471-2318-14-98.

8. Xin H, Kilgore ML, Sen BP, et al. Can nonurgent emergency department care costs be reduced? Empirical evidence from a U.S. nationally representative sample. J Emerg Med 2015; 49(3): 347-54, doi: 10.1016/j.jemermed.2015.01.034.

9. Stagg BC, Shah MM, Talwar N, et al. Factors affecting visits to the emergency department for urgent and nonurgent ocular conditions. Ophthalmology 2017; 124(5): 720-729, doi: 10.1016/j.ophtha.2016.12.039.

10. Uscher- Pines L, Pines J, Kellermann A, et al. Deciding to visit the emergency department for non-urgent conditions: a systematic review of the literature. Am J Manag Care 2013; 19(1): 47-59.

11. Honigman LS, Wiler JL, Rooks S, et al. National study of non-urgent emergency department visits and associated resource utilization. West J Emerg Med 2013; 14(6): 609-616.

12. Coe RM, Wolinsky FD, Miller DK, et al. Elderly persons without family support networks and use of health services: a follow-up report on social network relationships. Res Aging 1985; 7(4): 617-622.

13. Szatur-Jaworska B. Sytuacja rodzinna i więzi rodzinne ludzi starych i osób na przedpolu starości. In: Mossakowska M, Więcek A, Błędowski P, eds. Aspekty medyczne, psychologiczne, socjologiczne i ekonomiczne starzenia się ludzi w Polsce. Poznań 2012 [cited 15.03.2017]. Available from URL: http://ptg.otbd.pl/pliki/polsenior.pdf (in Polish).

14. BAROMETR WHC (Watch Health Care). Raport na temat zmian w dostępności do gwarantowanych świadczeń zdrowotnych w Polsce nr 15/3/12/2016. Stan na październik/listopad 2016 r. [cited 15.03.2017]. Available from URL: http://www.korektorzdrowia.pl/wp-content/uploads/barometrwhc_xv.final_-2.pdf (in Polish).

15. Rymaszewska J, Szmigiel A. Potrzeby osób w starszym wieku - definicje i narzędzia oceny. Psychoger Pol 2008; 5(2): 95-104 (in Polish).

16. Hrynkiewicz J. The situation of elderly people. Warszawa: Rządowa Rada Ludnościowa; 2012.

17. Kohlmann S, Kilbert MS, Ziegler K, et al. Supportive care needs in patients with cardiovascular disorders. Patient Educ Couns 2013; 91(3): 378-384.

18. Bonevski B, Sanson-Fisher R, Girgis A, et al. Evaluation of an instrument to assess the needs of patients with cancer. Cancer 2000; 88 : 217-225.

19. Kurpas D. Paradygmat opieki nad chorymi przewlekle w ramach podstawowej opieki zdrowotnej. Wrocław: Uniwersytet Medyczny im. Piastów Śląskich; 2013 (Rozprawy Habilitacyjne Uniwersytetu Medycznego we Wrocławiu; 6/2013) (in Polish).

20. Dobrzyńska E, Rymaszewska J, Kiejna A. CANSAS - Krótka Ocena Potrzeb Camberwell oraz inne narzędzia oceny potrzeb osób z zaburzeniami psychicznymi. Psychiatr Pol 2008; 12(4): 525-532 (in Polish).

21. Wieczorowska-Tobis K, Talarska D, Kropińska S, et al. The Camberwell Assesement of Need for the Elderly questionarie as a tool for the assesement of needs in the elderly individuals living in long - term care institutions. Arch Gerontol Geriatr 2016; 62: 163-168.

22. Beran D. Needs and Needs Assessments: a gap in the literature for chronic diseases. SAGE Open April-June 2015: 1-10, doi: $10.1177 / 2158244015580375$.

23. Alderfer CP. Existence, relatedness and growth. New York: Free Press; 1972.

24. Sauver JLS, Boyd CM, Grossardt BR, et al. Risk of developing multimorbidity across all ages in an historical cohort study: differences by sex and ethnicity. BMJ Open 2015; 5: e006413, doi: 10.1136/bmjopen-2014-006413.

25. van der Heide I, Snoeijs S, Melchiorre MG, et al. Innovating care for people with multiple chronic conditions in Europe. An overview. ICARE4EU [serial online] July 2015 [cited 03.01.2017]. Available from URL: http://www.nivel.nl/sites/default/files/bestanden/RapportState-of-the-Art-ICARE4EU.pdf.

26. Kurpas D, Wróblewska I, Kassolik K, et al. Unmet needs of patients with chronic respiratory diseases within primary healthcare. Adv Exp Med Biol 2015; 861: 43-55.

27. Samaras N, Chevalley T, Samaras D, et al. Older patients in the emergency department: a review. Ann Emerg Med 2010; 56(3): 261-269, doi: 10.1016/j.annemergmed.2010.04.015.

28. GUS. Jakość życia, kapitał społeczny, ubóstwo i wykluczenie społeczne w Polsce. Warszawa: GUS; 2013 (in Polish).

29. Ortiz H. Crossing new frontiers: benefits access among isolated seniors. National Center for Benefits Outreach and Enrollment (NCBOE). National Council on Aging [serial online] 2011 May [cited 12.02.2017]. Available from URL: https://www.ncoa.org/wp-content/uploads/crossing-new-frontiers.pdf.

30. Longman J, Passey M, Singer J, et al. The role of social isolation in frequent and/or avoidable hospitalisation: rural community-based service providers' perspectives. Aust Health Rev 2013; 37(2): 223-231, doi: 10.1071/AH12152.

31. Salvi F, Morichi V, Grilli A, et al. The elderly in the emergency department: a critical review of problems and solutions. Intern Emerg Med 2007; 2: 292-301.

32. Laudisio A, Marzetti E, Franceschi F, et al. Disability is associated with emergency room visits in the elderly: a population-based study. Aging Clin Exp Res 2015; 27(5): 663-671, doi: 10.1007/s40520-015-0324-5.

33. 2014 Disability Status Report: United States [serial online] 2014 [cited 08.01.2017]. Available from URL: https://www.disabilitystatistics.org/reports/2014/English/HTML/report2014.cfm?fips=2000000\#prev-state.

34. Hayes SL, McCarthy D, Radley D. The impact of a behavioral health condition on high-need adults, to the point. The Commonwealth Fund [serial online] 2016 Nov [cited: 03.01.017]. Available from URL: http://www.commonwealthfund.org/publications/blog/2016/ nov/behavioral-health-high-need-adults.

35. Shah MN, Jones CM, Richardson TM, et al. Prevalence of depression and cognitive impairment in older adult emergency medical services patients. Prehosp Emerg Care 2011; 15(1): 4-11. 
36. Rottenberg Y, Jacobs JM, Stessman J. Depression and health service utilization from age 70 to 85 : the Jerusalem Longitudinal Study. J Am Med Dir Assoc 2013; 14(9): 711.e1-6, doi: 10.1016/j.jamda.2013.06.001.

37. Nowicka-Sauer K, Pietrzykowska M, Staśkiewicz I, et al. Anxiety in patients with somatic diseases: important but marginalized problem. Fam Med Prim Care Rev 2015; 17(2): 120-123.

38. Nowicka-Sauer K, Beta S, Nowak R, et al. Anxiety following cardiac surgery - an important aspect of health status assessment. Fam Med Prim Care Rev 2016; 18(3): 317-320.

39. Lofters A, Guilcher S, Maulkhan N, et al. Patients living with disabilities: the need for high-quality primary care. Can Fam Physician 2016; 62(8): e457-464.

40. Kuzuya M, Hirakawa Y, Suzuki Y, et al. Association between unmet needs for medication support and all-cause hospitalization in community-dwelling disabled elderly people. J Am Geriatr Soc 2008; 56(5): 881-886, doi: 10.1111/j.1532-5415.2008.01676.x.

41. Morris JL. Explaining the elderly feminization of poverty: an analysis of retirement benefits, health care benefits, and elder care-giving. Notre Dame J Law Ethics Public Policy 2007; 21(2): 571-607.

42. Błędowski P, Szatur-Jaworska B, Szweda-Lewandowska Z, et al. Raport na temat sytuacji osób w wieku podeszłym w Polsce. Warszawa: Instytut Pracy i Spraw Socjalnych; 2012: 30-31 (in Polish).

43. World Health Organization. Western Pacific Region. Ageing. Facts sheet [serial online] 2014 July [cited: 11.01.2017]. Available from URL: http://www.wpro.who.int/mediacentre/factsheets/fs_201203_ageing/en/.

Tables: 3

Figures: 1

References: 43

Received: 27.03 .2017

Revised: 10.04 .2017

Accepted: 10.04.2017

Address for correspondence:

Katarzyna Szwamel, MSc

Państwowa Medyczna Wyższa Szkoła Zawodowa

ul. Katowicka 68

45-060 Opole

Polska

Tel.: +48 605 513-431

E-mail: k.szwamel@interia.pl 